\title{
Process-based distributed modeling approach for analysis of sediment dynamics in a river basin
}

\author{
M. A. Kabir ${ }^{1}$, D. Dutta ${ }^{1,2}$, and S. Hironaka ${ }^{3}$ \\ ${ }^{1}$ School of Applied Sciences and Engineering, Monash University, VIC, 3842, Australia \\ ${ }^{2}$ CSIRO Land and Water, Black Mountain, ACT, 2601, Australia \\ ${ }^{3}$ NEWJEC Inc., Koutou-ku, Tokyo, 135-0007, Japan \\ Received: 23 May 2010 - Published in Hydrol. Earth Syst. Sci. Discuss.: 16 August 2010 \\ Revised: 29 January 2011 - Accepted: 27 March 2011 - Published: 27 April 2011
}

\begin{abstract}
Modeling of sediment dynamics for developing best management practices of reducing soil erosion and of sediment control has become essential for sustainable management of watersheds. Precise estimation of sediment dynamics is very important since soils are a major component of enormous environmental processes and sediment transport controls lake and river pollution extensively. Different hydrological processes govern sediment dynamics in a river basin, which are highly variable in spatial and temporal scales. This paper presents a process-based distributed modeling approach for analysis of sediment dynamics at river basin scale by integrating sediment processes (soil erosion, sediment transport and deposition) with an existing processbased distributed hydrological model. In this modeling approach, the watershed is divided into an array of homogeneous grids to capture the catchment spatial heterogeneity. Hillslope and river sediment dynamic processes have been modeled separately and linked to each other consistently. Water flow and sediment transport at different land grids and river nodes are modeled using one dimensional kinematic wave approximation of Saint-Venant equations. The mechanics of sediment dynamics are integrated into the model using representative physical equations after a comprehensive review. The model has been tested on river basins in two different hydro climatic areas, the Abukuma River Basin, Japan and Latrobe River Basin, Australia. Sediment transport and deposition are modeled using Govers transport capacity equation. All spatial datasets, such as, Digital Elevation Model (DEM), land use and soil classification data, etc., have been prepared using raster "Geographic Information System (GIS)" tools. The results of relevant statistical
\end{abstract}

Correspondence to: M. A. Kabir

(aynul.kabir@monash.edu) checks (Nash-Sutcliffe efficiency and $R$-squared value) indicate that the model simulates basin hydrology and its associated sediment dynamics reasonably well. This paper presents the model including descriptions of the various components and the results of its application on two case study areas.

\section{Introduction}

Soil erosion and excessive sedimentation are recognized as a major problem arising from deforestation, agricultural intensification, urbanization and land degradation. Water induced soil erosion rate has been found to be increasing in many watersheds around the world and the rate is likely to be exacerbated as a result of global climatic change. More seriously, many significant environmental resources such as streams, lakes, coasts, and aquatic biodiversity can be impacted by sediment associated contaminants (Hograth et al., 2004). The worsening impacts of extensive sediment dynamics in a watershed include river bank erosion and river bed aggradations, which increase floodplains and flood frequency by decreasing flow capacity. Agricultural productivity lessening by removing fertile topsoil is one of the major consequences of watershed sediment dynamics (Fiener et al., 2008). The other major consequences include reducing reservoir capacity, washing out of road culverts and disrupting landscape appearance via formation of rill and gullies (Mughal, 2001; Noel, 2001; Svoray and Ben-Said, 2010). The development of effective solutions to this problem therefore requires quantitative and accurate estimation of soil erosion rate, sediment transport and deposition at spatial locations of headwaters, main stem regions, riparian and entire watershed.

Published by Copernicus Publications on behalf of the European Geosciences Union. 
Sediment dynamics in a river basin can be estimated both quantitatively and consistently by using modeling tools (Bhattarai and Dutta, 2007). Basin scale process-based distributed approach is advantageous for modeling sediment delivery processes since eroded sediments are produced from different sources throughout a basin (Ferro and Porto, 2000). A number of process-based sediment transport models have been produced by researchers over the past four decades (Bhattacharya et al., 2007), such as European Soil Erosion Model (EUROSEM) (Morgan et al., 1993), Water Erosion Prediction Project (WEPP) (Nearing et al., 1989), Areal Nonpoint Source Watershed Environment Response Simulation (ANSWERS) (Beasley et al., 1980), etc. Among these models, EUROSEM introduced by Morgan et al. (1993) and then extensively reviewed and applied by Morgan et al. (1998), simulates hillslope sediment processes well using a processbased distributed modeling approach. EUROSEM considers effects of plant cover on interception and rainfall energy, effect of different soil types on infiltration, flow velocity and splash erosion; and simulates rill and interrill flow using transport capacity of runoff relationships, which is based on over 500 experimental observations of shallow surface flows (Morgan et al., 1998). The model calculates sediment concentration and determines total soil loss, storm sediment graph after estimating total runoff, total storm hydrograph (Morgan et al., 1998). EUROSEM does not consider sediment dynamics in river systems separately. Another model, WEPP, introduced by US Department of Agriculture (Flanagan and Nearing, 1995), is able to estimate hillslope soil erosion and sediment movement using process-based distributed hydrological modeling. The WEPP consists of a stochastic weather model, a modified version of Green-Ampt infiltration equation, Simulator for Water Resources in Rural Basins (SWRRB) model, Erosion Productivity Impact Calculator (EPIC) model, and scaling components for irrigation and decomposition of plant residues (Chmelova and Sarapatka, 2002). WEPP is applicable only to small watersheds (Duna et al., 2009). The ANSWERS model, introduced by Beasley et al. (1980), is capable of simulating soil erosion and sediment transport through a process-based distributed modeling approach. The model uses soil, land use, elevation data and channel properties to predict runoff and erosion quantitatively. The model was developed by using Foster and Meyer (1972) equation for simulating soil erosion and sediment transport; and Huggins and Monke (1966) for water routing (Borah and Bera, 2003). The model calculates runoff using empirical relationships and is suitable for agricultural areas. Jain et al. (2005) carried out detail GIS based sediment modeling via spatially distributed rainfall-runoff simulation. Flow direction has been determined here using the eight-direction pour point algorithm (Jenson and Domingue, 1988) along the steepest descent direction. The study used comprehensive physical equations to represent hillslope soil erosion and continuity equations to simulate sediment movements.
Sediment dynamics in river systems are much more complex than those in hillslope areas and become progressively more significant in large catchment areas (Apip et al., 2008), since sediment transport is highly sensitive to the flow hydraulics (Aksoy and Kavvas, 2005). Ferro and Porto (2000) emphasized the need of modeling of the hillslope and channel sediment processes separately. Many of the existing models listed above do not model the sediment processes in channels separately with required details. Many of those models were developed focusing on one or two elements in a river basin, while the other elements were estimated conceptually and some were prepared to address site specific issues only. Prediction errors of some of the available soil erosion and sediment transport models have been found to be unacceptably high due to the adoption of major assumptions and oversimplifications of an immensely complex naturally occurring sediment transport process (Bhattacharya et al., 2007). Several recommendations have been made for further improvements in sediment modeling approach by different authorities after comprehensive evaluation of existing sediment models. These include: (i) need to accurately represent the driving hydrological processes, (ii) setting different process scales properly, (iii) addressing event based hydrology, (iv) strengthening hillslope processes and in-stream dynamics-deposition link, and (v) determining fractional sediment loads, etc (Post et al., 2007).

This study has aimed to develop a process-based sediment dynamic model considering hillslope sediment micromechanics using a distributed modeling approach that models the surface and river systems separately. The model has been developed by integrating soil erosion-sediment transport processes with the distributed hydrological model developed by Dutta et al. (2000). Hillslope sediment dynamics has been represented by appropriate physical equations selected after a comprehensive review of the existing literature (e.g., Torri et al., 1987; Brandt, 1989, 1990; Smith et al., 1995; Morgan et al., 1998; Jain et al., 2005). The water flow and sediment transport at different land grids and river nodes have been modeled using one-dimensional kinematic wave approximation of Saint-Venant equations. A simplified form of transport capacity equation (Govers, 1990) has been used for simulating sediment transport both hillslope and channel areas. This paper introduces the developed model and describes its applications in two river basins with distinct climatic and hydro-geological characteristics. The present study has focused only on the suspended sediment simulation in the river basin, where clay and very fine silt were excluded.

\section{Model development}

The development of the process-based sediment dynamic model involved several steps including: (i) adoption of an existing distributed hydrological model (DHM), (ii) understanding and interpretation of basin sediment dynamics by 
suitable physical laws, (iii) development of soil erosion, sediment transport and deposition modules for channel and hillslope areas separately and integration of these modules with the DHM consistently.

\subsection{Hydrological modeling}

The distributed hydrological model (DHM) developed at University of Tokyo (Dutta et al., 2000) has been adopted in this study. The model was tested and well calibrated for different regions around the world (Dutta and Nakayama, 2008). It divides the catchment into an array of homogeneous grid cells to capture the catchment heterogeneity. It represents all the components of the hydrologic cycle mathematically based on their physical governing equations and then simulates the movement of water from cell to cell using the principles of conservation of mass and momentum. All the hydrologic components are grouped here as five distinct modules: (i) interception and evapotranspiration simulation module, (ii) unsaturated zone flow simulation module, (iii) saturated zone flow simulation module, (iv) overland flow simulation module and (v) channel network flow simulation module.

The interception and evapotranspiration simulation module estimates total loss of water by calculating intercepted water in leaf area, evaporated water from soil surface and transpirated water from vegetation before rainfall generates runoff. The model uses BATS concept and Kristensen and Jensen Model for estimating interception and Evapotranspiration, respectively. The unsaturated zone module simulates the movement of water considering soil infiltration rate and soil moisture content in root zone using threedimensional Richard's equation. Saturated zone module uses two-dimensional Boussinesq's equation to simulate the subsurface water flow where all the voids in soil are filled with water. Overland flow simulation module solves the hydrological parameters in each land grid and estimates the amount of lateral flow discharging into the river systems. The channel network flow simulation module calculates hydrological parameters in each river nodes considering hydraulic parameters associated with flow path and the lateral flow coming to river systems from surface area. The principles of different modules are summarized in Table 1.

Although the model is capable of simulating back water effect using two-dimensional and one-dimensional diffusive wave approximations of the Saint-Venant continuity and momentum equations at surface and river areas, respectively, a one-dimensional kinematic wave approximation can also be suitably applied in this model at both areas when the flow is unidirectional and back water effect is insignificant. In that case, the model simulates surface and river flow movements based on the direction of steepest descent among the eight adjacent cells. The kinematic wave approximation reduces computational time considerably and is efficient when simulating large scale river basin incorporating other modules
Table 1. Principles of DHM (Dutta et al., 2000).

\begin{tabular}{ll}
\hline Modules & Principles \\
\hline Evapo-transpiration module & $\begin{array}{l}\text { Interception: (BATS concept) } \\
\text { Evapotranspiration } \\
\text { (Kristensen and Jensen Model) }\end{array}$ \\
Unsaturated zone module & $\begin{array}{l}\text { Unsaturated Zone } \\
\text { (3-D Richard's equation) }\end{array}$ \\
Saturated zone module & $\begin{array}{l}\text { Saturated Zone } \\
\text { (2-D Boussinesq's equation) }\end{array}$ \\
Overland flow module & Continuity and Momentum \\
& equations \\
& One-dimensional kinematic wave \\
& approximation of Saint-Venant \\
equation & Continuity and Momentum \\
River flow module & equations \\
& One-dimensional kinematic wave \\
& approximation of Saint-Venant \\
& equation with satisfying courant \\
& condition
\end{tabular}

along with watershed hydrology. The different modules in the adopted distributed hydrological model were developed by using FORTRAN programming language for computer simulation.

\subsection{Sediment dynamic modules}

The sediment modules include sediment processes such as, soil erosion, sediment transport and deposition, with the driving hydrological components. The modules represent soil erosion by estimating soil detachment due to raindrop impact and the shearing force of flowing water on the basis of established physical equations. Rainfall impacts are categorized into direct rainfall impact and leaf drip impact. Sediment transport is simulated by using the governing equations of conservation of mass and momentum and a concept of transport capacity concentration. Soil detachments by flow and sediment deposition are estimated using the concept of transport capacity concentration. The concept of the processbased watershed sediment dynamics is shown in Fig. 1.

Hillslope areas limit the amount of sediment delivering to river systems based on land surface characteristics including elevation, soil, vegetation cover, and underlying geology (Jain et al., 2005). Sediment dynamics of hillslope areas is highly variable in both spatial and temporal scales and plays the most significant role in basin sedimentology. Sediment dynamics in the basin hillslopes consist of distinct physical processes which need to be considered and modeled separately (Ferro and Porto, 2000). Sediment dynamics within the channel network differ from hillslope sediment processes and also reveal as a significant factor in total 


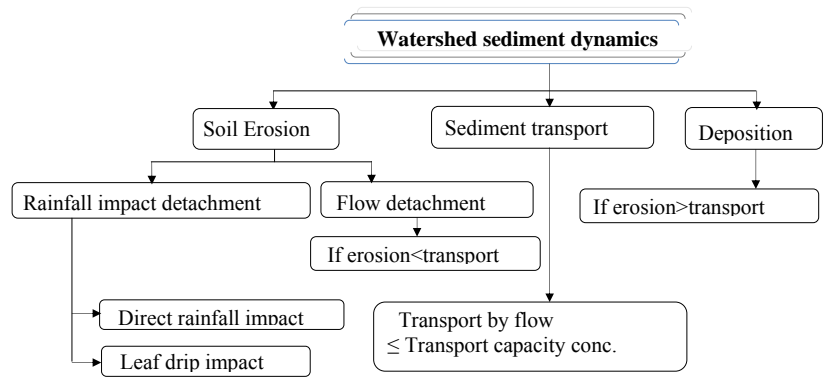

Fig. 1. Process-based approach of watershed sediment dynamics (after Foster, 1982).

sediment budgeting in a catchment (Atkinson, 1995; Ferro and Porto, 2000). Thus, the river and hillslope sediment dynamics have been modelled separately.

In this modeling approach, hillslope soil detachment by rainfall impact is estimated using the kinetic energy delivered by rainwater when raindrops strike soil particles during a storm event. This kinetic energy is considered to be different for direct rainfall impact and leaf drip impact. Brandt (1989) derived an equation using rainfall intensity to calculate the kinetic energy for direct rainfall impact (Eq. 1). Relating canopy height to kinetic energy for leaf drip impact conditions, Brandt (1990) also proposed a relationship as shown in Eq. (2). The total Kinetic energy then can be described by Eq. (3).

$\mathrm{KE}(\mathrm{DT})=8.95+8.44 \log (I)$

$\mathrm{KE}(\mathrm{LD})=15.8(\mathrm{PH})^{0.5}-5.87$

$\mathrm{KE}=\mathrm{KE}(\mathrm{DT}) \cdot\left(1-C_{\mathrm{C}}\right) \cdot H_{\mathrm{Total}}+\mathrm{KE}(\mathrm{LD}) \cdot C_{\mathrm{C}} \cdot H_{\mathrm{Net}}$

Where, KE (DT) and KE (LD) is the kinetic energy in $\mathrm{J} \mathrm{m}^{-2} \mathrm{~mm}^{-1}$ for direct rainfall impact and leaf drip impact conditions, respectively. $H_{\mathrm{Net}}$ is the depth of net rainfall in $\mathrm{mm}$ which is estimated by deducting the interception loss of water from the depth of total rainfall $\left(H_{\text {Total }}\right.$ in $\left.\mathrm{mm}\right)$. I is the rainfall intensity in $\mathrm{mm} \mathrm{h}^{-1}$ and $\mathrm{PH}$ is the canopy height in $\mathrm{m}$. The total $\mathrm{KE}$ in $\mathrm{J} \mathrm{m}^{-2}$ is calculated by introducing canopy coverage factor $C_{\mathrm{C}}$ as shown in Eq. (3). The $C_{\mathrm{C}}$ is estimated from land use data on a scale of 0.0 to $1.0 ; 0$ for bare land and 1.0 for highly dense forest area.

Torri et al. (1987) related total kinetic energy to the amount of detached soils by rainfall impact as shown in Eq. (4).

$\mathrm{DR}=\frac{k}{\rho_{\mathrm{s}}}(\mathrm{KE}) e^{-Z h}$

Where, DR is the soil detachment by rainfall impact in $\mathrm{m}^{3} \mathrm{~s}^{-1} \mathrm{~m}^{-1}, k$ is the soil detachability index in $\mathrm{gj}^{-1}, \rho_{\mathrm{s}}$ is the soil density in $\mathrm{kg} \mathrm{m}^{-3}, e^{-Z h}$ is the correction factor for water ponding where $Z$ depends on soil texture, typical value lies in-between 0.9 to 3.9 and $h$ is surface water depth in $\mathrm{m}$.
The value of this correction factor decreases from 1.0 to towards 0.0 for the increase of $h$ from $0.0 \mathrm{~m}$. Park et al. (1982) proposed an equation (Eq. 5) to estimate water ponding correction factor to calculate soil detachment by rainfall impact using median raindrop diameter. The use of rainfall intensity and raindrop diameter relationship (Eq. 6) derived by Laws and Parsons (1943) as described in Jain et al. (2005) makes the latter mentioned water ponding correction factor easier to estimate.

$$
\begin{array}{rlrl}
F_{\mathrm{W}} & =\exp \left(1-h / D_{\mathrm{m}}\right) & \text { if } h>D_{\mathrm{m}} \\
& =1 & & \text { if } h \leq D_{\mathrm{m}}
\end{array}
$$

$D_{\mathrm{m}}=0.00124 I^{0.182}$

Where, $F_{\mathrm{W}}$, as an alternative of $e^{-Z h}$ in Eq. (4), is the water depth correction factor ranging from 1.0 to $0.0, h$ is water depth in $\mathrm{m}, D_{\mathrm{m}}$ is the raindrop diameter in $\mathrm{m}, I$ is the rainfall intensity in $\mathrm{mm} \mathrm{h}^{-1}$.

Soil detachments by flow and sediment deposition are practically two mutually exclusive events. But, both the processes are considered to work on simultaneously in most of the modeling approaches. Flow detachment or deposition can be expressed by Eq. (7) as described by Morgan et al. (1998) using the generalized erosion-deposition theory proposed by Smith et al. (1995). In this equation, transport capacity concentration (TC) is a baseline defined by a hypothetical concept which reflects a sediment concentration that balances the rate of erosion by flow and the accompanying rate of deposition.

$\mathrm{DF}=\beta_{\mathrm{S}} w v_{\mathrm{S}}\left(\mathrm{TC}-C_{\mathrm{S}}\right)$

Where, DF is the flow detachment or deposition in $\mathrm{m}^{3} \mathrm{~s}^{-1} \mathrm{~m}^{-1}$ for sediment concentration $C_{\mathrm{S}}\left(\mathrm{m}^{3} \mathrm{~m}^{-3}\right), w$ is the width of the flow in $\mathrm{m}, v_{\mathrm{s}}$ is the particle settling velocity in $\mathrm{m} \mathrm{s}^{-1}$ and $\beta_{\mathrm{S}}$ is a correction factor to calculate cohesive soil erosion. In case of cohesive soil, cohesion force encounters detachment processes. Thus, $\beta_{\mathrm{S}}$ is equal to 1.0 for non-cohesive soil detachment or any form of deposition but it decreases from 1.0 to towards 0.0 with high cohesive values of soil during detachment as shown in Eq. (8).

$\beta_{\mathrm{s}}=0.79 e^{-0.85 \mathrm{~J}}$

Where, $J$ is the soil cohesion in $\mathrm{kPa}$. Several methods have already been developed to estimate transport capacity based on flow rate, sediment size, stream power, critical shear stress, etc. The Govers (1990) transport capacity equation has been selected for modeling due to its simple structure and the requirement of easily available input dataset. The Govers transport capacity equation was developed for rill flow based on 500 experiments that were carried out on a range of materials from silt to coarse sand focusing median grain sizes $\left(d_{50}\right)$ with slopes from 1 to 15 percent and discharges 


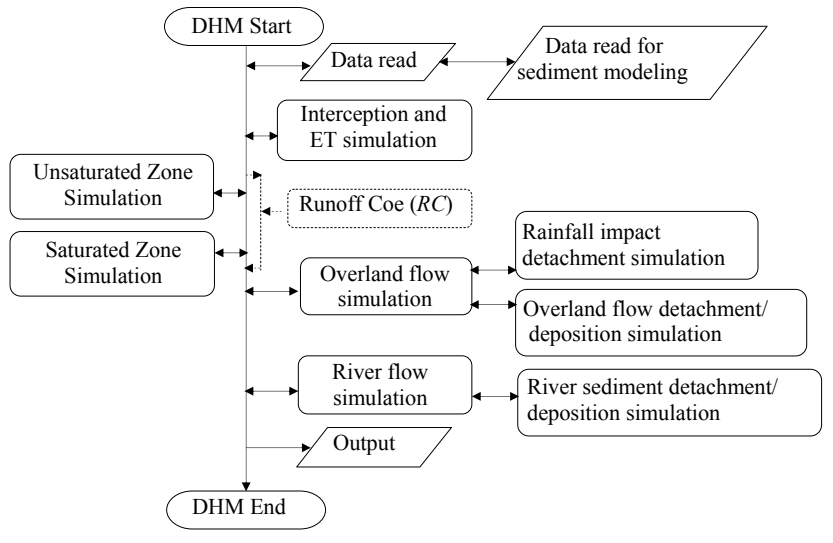

Fig. 2. Structure of the process-based sediment dynamic model.

from 2 to $100 \mathrm{~cm}^{3} \mathrm{~cm}^{-1} \mathrm{~s}^{-1}$ (Morgan et al., 1998). Eq. (9) shows the expressions of Govers TC as mentioned in Morgan et al. (1998) in terms of a hydraulic variable named unit stream power $(\omega)$ and $d_{50}$ which were calibrated for any particle size ranging from 50 to $250 \mu \mathrm{m}$ with maximum sediment concentrations up to $0.32 \mathrm{~m}^{3} \mathrm{~m}^{-3}$.

$$
\begin{aligned}
\mathrm{TC} & =c\left(\omega-\omega_{\mathrm{cr}}\right)^{\eta} ; \omega=10 V s ; c=\left[\left(d_{50}+5\right) / 0.32\right]^{-0.6} ; \\
\eta & =\left[\left(d_{50}+5\right) / 300\right]^{0.25}
\end{aligned}
$$

Where, TC is the transport capacity in $\mathrm{m}^{3} \mathrm{~m}^{-3}, \omega$ is the unit stream power in $\mathrm{cm} \mathrm{s}^{-1}, V$ is the mean flow velocity in $\mathrm{m} \mathrm{s}^{-1}, \mathrm{~s}$ is the slope in percentage, $\omega_{\mathrm{cr}}$ is the critical value of unit stream power and the value is $0.4 \mathrm{~cm} \mathrm{~s}^{-1}$ considered in Govers equation, $c$ and $\eta$ are coefficients depending on median particle size, $d_{50}$ of the soil as in mum.

The sediment modules have been developed and interpreted under FORTRAN programming environment to make compatible to the adopted distributed hydrological model and are incorporated as sub-components within the DHM environment. The overall sediment dynamic model indicating different modules and their simulation sequence is shown in Fig. 2.

\section{Solution scheme}

The movement of sediments in each discretized cell is determined by associating them with water discharge based on the principle of conservation of mass and momentum similar to the flow simulation in the DHM as stated earlier. The one-dimensional kinematic wave approximation is applied to simulate flow and sediment transport in both land grids and river nodes along the steepest descent direction. As sediment transport is primarily associated with flow, sediment transport estimation becomes much easier since calculation processes are set to be started just after the simulation of water discharge and head in land grids or river nodes within the same time interval. The backward finite-difference

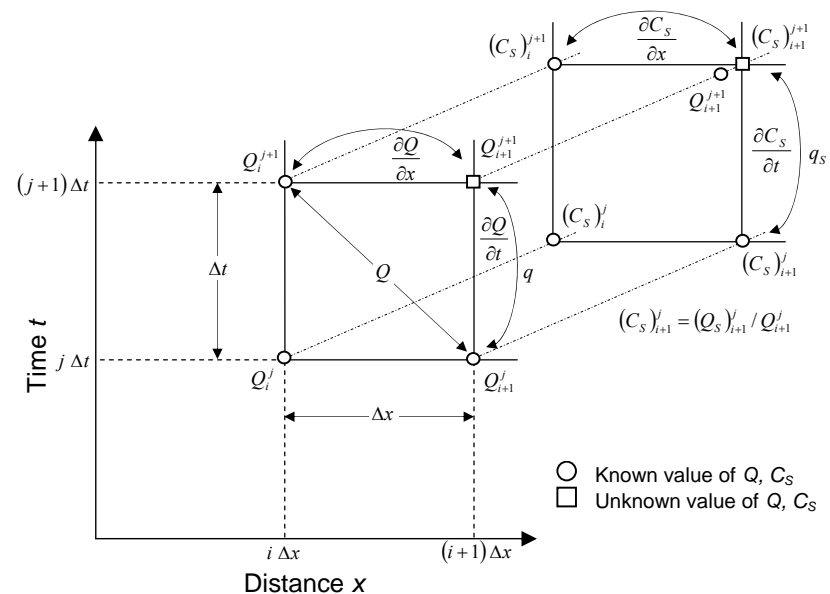

Fig. 3. Time and space derivatives of both $Q$ and $C_{\mathrm{s}}$ by finitedifference scheme in kinematic modeling (after Chow, 1959).

scheme has been taken into consideration in solving kinematic wave equations numerically. The approximations of time and space derivatives of flow $(Q)$ and sediment concentration $\left(C_{\mathrm{s}}\right)$ on $\mathrm{x}$-t grid are shown in Fig. 3. The kinematic wave equations and their finite-difference interpretations are presented in Table 2. The meaning of different symbols used is appended at the end.

The mass-balance equations (Table 2) have been applied on land grids along the order of flow accumulation values and in river nodes from upstream to downstream. ArcGIS 9.3 developed by Environmental Systems Research Institute (ESRI) has been used to generate river network and flow accumulation maps from a digital elevation model. Flow accumulation map is produced from a flow direction map which is determined based on Eight-direction pour point algorithm (Jenson and Domingue, 1988). The lateral flow in land grids is estimated from rainfall to route water whereas in sediment transport calculation, the amount of rainfall impact detachment and flow detachment are considered as lateral sediment supply in the land grids (Table 3a). The lateral flows for solving mass-balance equations in river nodes are determined by estimating water discharge and sediment loads coming from land grids to river grids adjacent to the river nodes to route water discharge and sediment concentration, respectively (Table 3b, c). At confluence points, water discharge and sediment loads are calculated by adding all the incoming flows and sediment loads algebraically; and sediment concentrations are determined by dividing sediment load by respective water discharge (Table 3d). The solution approaches for flow and sediment transport in distributed areas are shown in Fig. 4 and described in Table 3. 
Table 2. Kinematic wave equations and finite difference interpretation.

\begin{tabular}{ll}
\hline Equations for solution of “ $Q$ ” & Equations for solution of " $C_{S}$ ” \\
\hline$\frac{\partial Q}{\partial x}+\alpha \beta Q^{\beta-1} \frac{\partial Q}{\partial t}=q$ & $\frac{\partial Q_{\mathrm{S}}}{\partial x}+\frac{\partial A_{\mathrm{S}}}{\partial t}-e(x, t)=q_{\mathrm{S}}$ \\
Where, $A=\left(\frac{n P^{2 / 3}}{s^{1 / 2}}\right)^{3 / 5} Q^{3 / 5}=\alpha Q^{\beta}$ & Where, $Q_{\mathrm{S}}=Q C_{\mathrm{S}} ; Q=A V ; Q \mathrm{~S}=A_{\mathrm{S}} V$ \\
$\frac{Q_{i+1}^{j+1}-Q_{i}^{j+1}}{\Delta x}+\alpha \beta\left(\frac{Q_{i+1}^{j}+Q_{i}^{j+1}}{2}\right){ }^{\beta-1} \frac{Q_{i+1}^{j+1}-Q_{i+1}^{j}}{\Delta t}=\frac{q_{i+1}^{j+1}-q_{i+1}^{j}}{2}$ & $\frac{\partial\left(Q C_{\mathrm{S}}\right)}{\partial x}+\frac{\partial\left(\frac{Q C_{\mathrm{S}}}{V}\right)}{\partial t}-e(x, t)=q_{\mathrm{S}}, \quad e(x, t)=\mathrm{DR}+\mathrm{DF}$ \\
& $\frac{\left(Q C_{\mathrm{S}}\right)_{i+1}^{j+1}-\left(Q C_{\mathrm{S}}\right)_{i}^{j+1}}{\Delta x}+\frac{\left(\frac{Q C_{\mathrm{S}}}{V}\right)_{i+1}^{j+1}-\left(\frac{Q C_{\mathrm{S}}}{V}\right)_{i+1}^{j}-[e(x, t)]_{i+1}^{j+1}=\frac{\left(q_{\mathrm{S}}\right)_{i+1}^{j+1}-\left(q_{\mathrm{S}}\right)_{i+1}^{j}}{2}}{}$
\end{tabular}

Table 3. Solution approaches for flow and sediment transport in distributed areas (as described in Fig. 4).

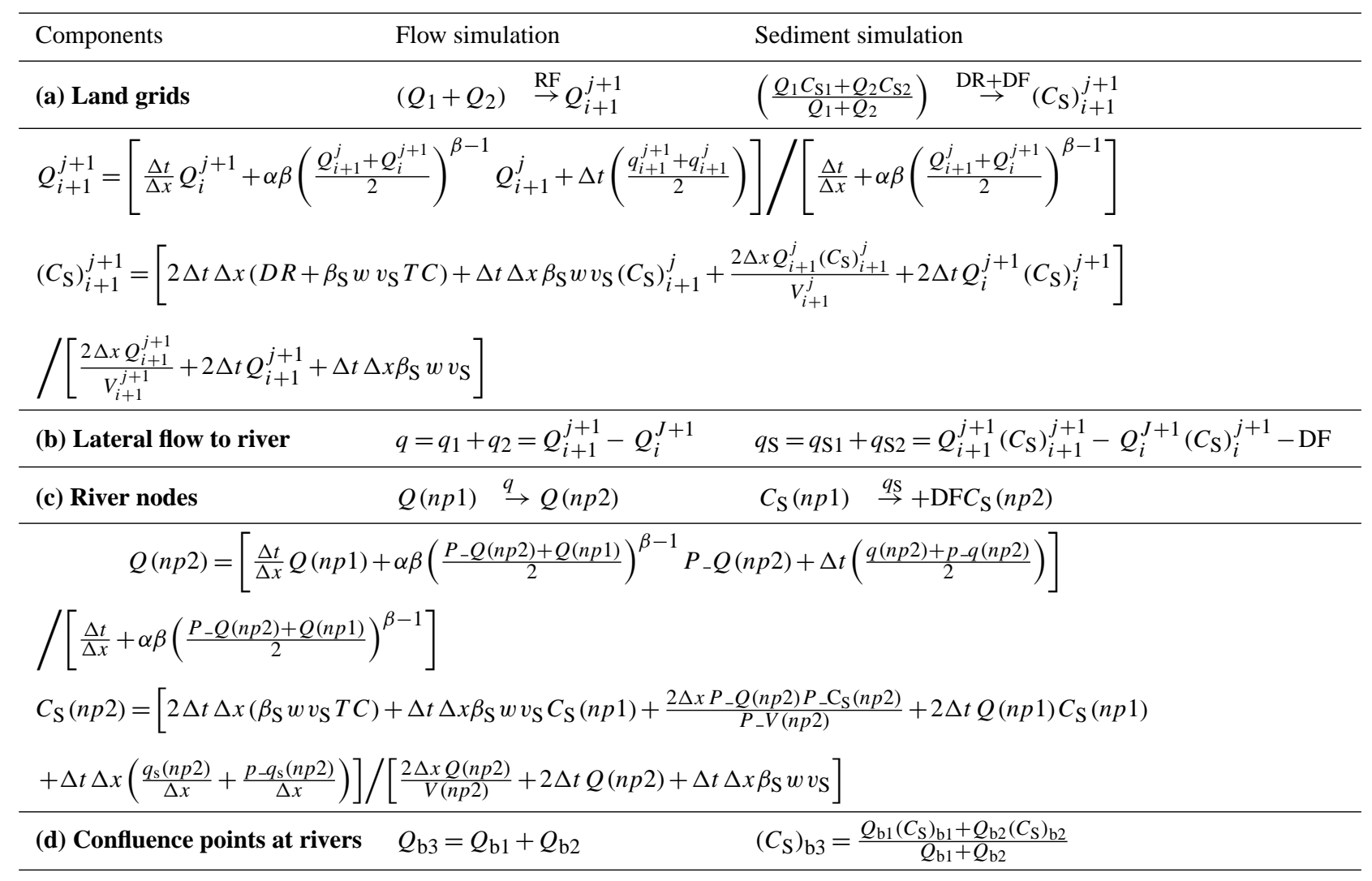

\section{Model applications}

The model has been tested on two different hydro climatic areas in Japan (Abukuma River Basin) and in Australia (Latrobe River Basin). These two study areas are distinct in terms of rainfall, slope and water discharge as shown in Table 4. Higher average slopes in Abukuma River Basin result in a low time of concentration in comparison with Latrobe River Basin. Abukuma River Basin also experiences higher rainfall than Latrobe River Basin. The two different hydro climatic areas have been chosen as study areas to analyze the applicability of the model in different regions.
Table 4. Characteristics of the study areas.

\begin{tabular}{|c|c|c|c|}
\hline Study areas & $\begin{array}{l}\text { Annual avg. } \\
\mathrm{RF}(\mathrm{mm})\end{array}$ & $\begin{array}{l}\text { Avg. Slope } \\
\text { in } \%\end{array}$ & $\begin{array}{l}\text { Max. daily avg. } \\
\mathrm{Q}\left(\mathrm{m}^{3} \mathrm{~s}^{-1}\right)\end{array}$ \\
\hline Abukuma River & 1302.0 & 6.57 & 4804.25 \\
\hline Basin, Japan & (in 2002) & & (in 2002 at Tateyama) \\
\hline Latrobe River & 975 & 4.9 & 16.18 \\
\hline Basin, Australia & (BRS and BOM, 2008) & & (2007 at Rosedale) \\
\hline
\end{tabular}




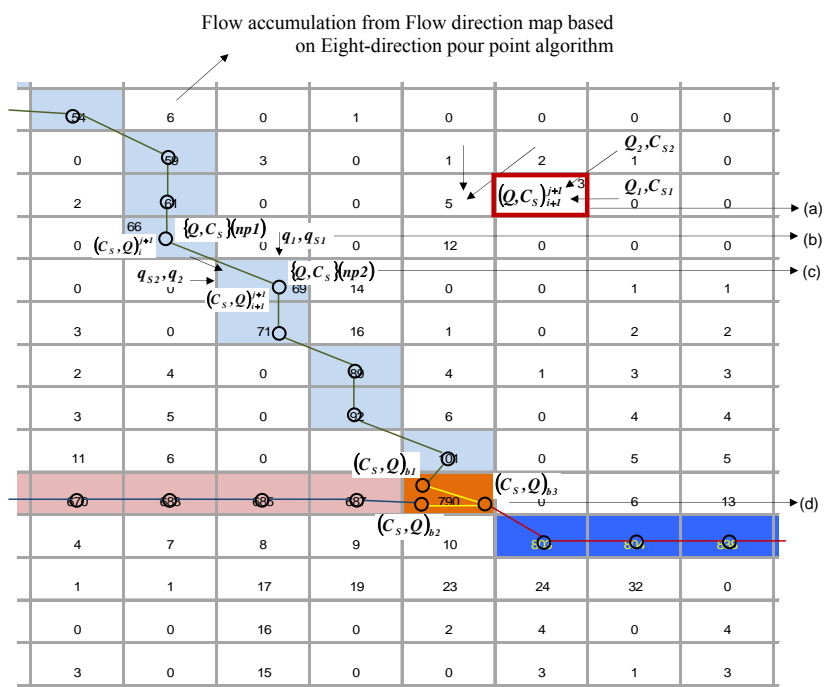

Fig. 4. Solution approaches for flow and sediment transport in distributed areas (description shown in Table 3).

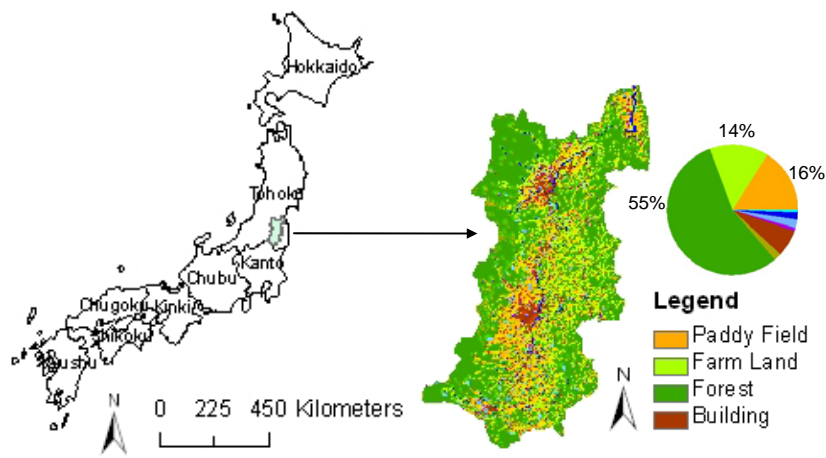

(a)

(b)

Fig. 5. Abukuma River Basin location in Japan and land use map.

\subsection{Study area 1 (Abukuma River Basin, Japan)}

Abukuma is the 6th longest river in Japan and starts from the Nasu Mountains in Tohoku region. The river flows mostly northwards throughout the basin areas and ultimately drains into the Pacific Ocean near the city of Kakuda (Fig. 5a). The river basin is about $5390 \mathrm{~km}^{2}$ covered by mainly forest areas (Fig. 5b) with the main stream of $234 \mathrm{~km}$ in length. The basin sustains a population of 1.2 million and comprises major cities such as Shirakawa, Sukagawa, Koriyama, Nihonmatsu, Fukushima, Kakuda, etc. Abukuma River also consists of many tributaries and has very steep gradients in many locations.

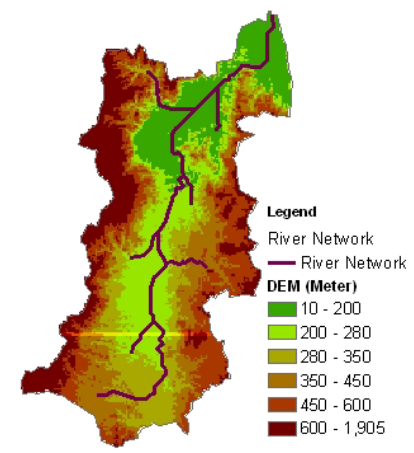

(a) DEM

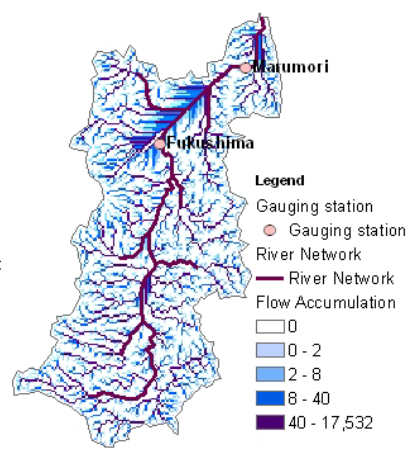

(b) Flow accumulation map
Fig. 6. Spatial data overview for Abukuma River Basin modelling.

\subsubsection{Model setup}

The model has been set up to simulate a flood event occurred in July 2002 at Abukuma River Basin, Japan. Only measured daily water discharge data is available throughout the period. Measured hourly water and sediment flow data is available in flood peak hours. The digital elevation model (DEM) of 500-m grid spacing has been used in simulation as shown in Fig. 6a, which was generated from 50-m resolution point elevation data. Figure $6 \mathrm{~b}$ shows flow accumulation map, which has been derived from the DEM using the eight-direction pour point algorithm (Jenson and Domingue, 1988). The river network that has been used for simulation is also shown in the same figure, where Tateyama and Fukushima are the two river gauging stations selected for model calibration and verification. The river network was delineated from flow accumulation map by choosing the threshold values for channel initiation. The sub-catchments near the Pacific Ocean have not been considered in this kinematic wave simulation since those areas are subjected to tidal effects.

The temporal resolution has been set to 1-h during model simulation. The model stability checking and temporal resolution refining have also been carried out based on the satisfaction of Courant condition. For simplifying the simulation, the overland runoff volume has been estimated by introducing a constant runoff coefficient instead of modeling saturated and unsaturated zone; and the base flow effects were neglected during river flow comparison. The concept of runoff coefficient is still widely used for many practical purposes (Merz et al., 2006). It is revealed that a runoff coefficient of 0.72 has allocated water distributions properly for hydrological simulations at Abukuma River Basin. Roughness coefficient $(n)$ values in surface and river areas were considered as the main calibrating parameter for hydrological simulation that have been evaluated from land use and other topographical information of this basin. An index of soil detachability $(k)$ has been considered another main calibrating parameter for sediment modeling and its range is 

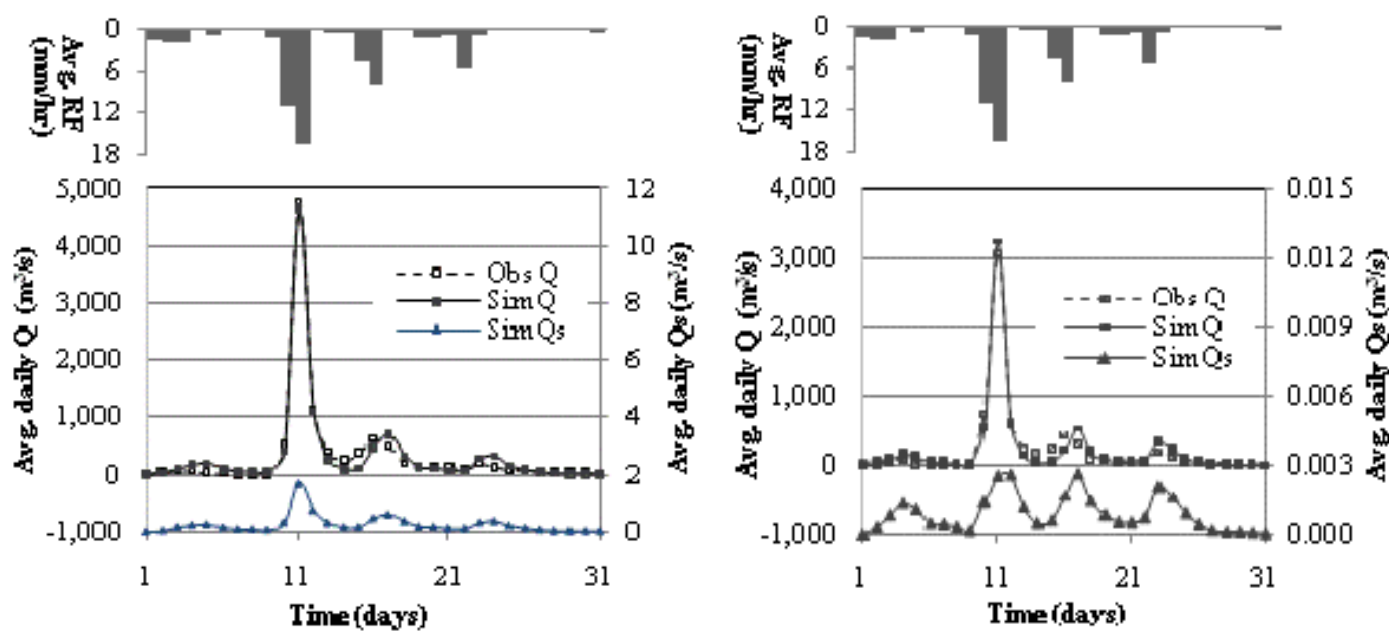

Fig. 7. Daily avg. water and suspended sediment discharge.

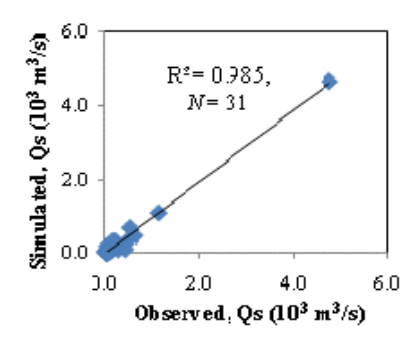

(a) At Tateyama

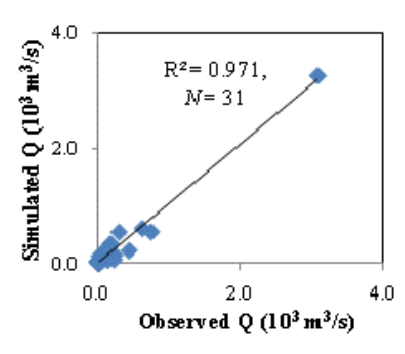

(b) At Fukushima

Fig. 8. Correlation of observed and simulated daily avg. water discharge ( $N=$ number of observations).

highly related to soil texture. The theoretical range of values for soil detachability index is 0.01 to $10 \mathrm{~g} \mathrm{j}^{-1}$, where maximum values for sand and minimum values for clay (Gumiere et al., 2009; Morgan et al., 1998; Morgan, 2001).

\subsubsection{Simulations and discussion}

The basin is highly sensitive to rainfall for flood discharge in river systems. The basin generates a high rate of overland flow due to hilly topography as well as to have a low time of concentration. The water budget distributions at Abukuma River Basin in July 2002 are revealed as $70.05 \%$ of overland flow, $26.57 \%$ of infiltration, $3.38 \%$ of interception and evapotranspiration through simulations of different hydrological processes.

Figure $7 \mathrm{a}, \mathrm{b}$ shows the simulated results of the average daily water and suspended sediment (SS) discharge together with the observed data at Tateyama and Fukushima river gauging stations and the basin average rainfall. Based on available measured data, it is found that the model has simulated well the daily average flood water discharge at these

Table 5. Performance evaluation of hydrological and sediment modeling.

\begin{tabular}{llrr}
\hline Items & Stations & $\begin{array}{r}\text { Nash-Sutcliffe's } \\
\text { COE }\end{array}$ & $\begin{array}{r}\text { COE of } \\
\text { determination }\end{array}$ \\
\hline Avg. daily, $Q$ & Tateyama & 0.986 & 0.985 \\
& Fukushima & 0.969 & 0.971 \\
Hourly, $Q$ & Tateyama & 0.843 & 0.931 \\
Hourly, $Q \mathrm{~s}$ & Tateyama & -4.26 & -7.79 \\
$\left(Q \mathrm{~s}>2 \mathrm{~m}^{3} \mathrm{~s}^{-1}\right)$ & & & \\
Hourly, $Q \mathrm{~s}$ & Tateyama & 0.88 & 0.87 \\
$\left(Q \mathrm{~s}<2 \mathrm{~m}^{3} \mathrm{~s}^{-1}\right)$ & & & \\
\hline
\end{tabular}

two gauging stations. The correlation coefficients $\left(R^{2}\right.$ values) are 0.985 and 0.971 between daily average observed and simulated water discharge at Tateyama and Fukushima stations, respectively as shown in Fig. 8. Table 5 shows that a high Nash-Sutcliffe's coefficients of 0.986 and 0.969 are also between simulated and observed daily average flows at these two stations, respectively. The simulated daily suspended sediment (SS) discharge data were not shown here with the observed value due to the unavailability of data in the daily scale. However, the simulated daily average suspended sediment (SS) discharge follows a similar trend as water flows in both stations.

As stated earlier, the flood event was simulated using 1-h temporal resolution to capture the temporal variations. High resolution of temporal and spatial datasets are extremely desirable to strengthen the performance of the model through proper calibration and verification, since the average values can reflect total water budget but fail to depict the peaks and troughs accurately and precisely. For this, the simulation results have been further compared with available hourly data of 11 July 2002 at Tateyama station. Figure 9 shows 


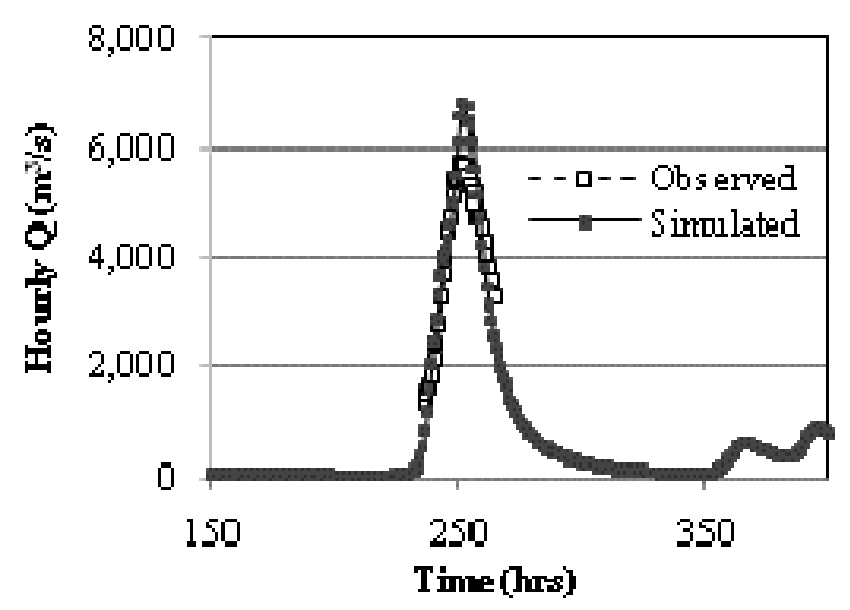

Fig. 9. Hourly water discharge at Tateyama station (11 July 2002).

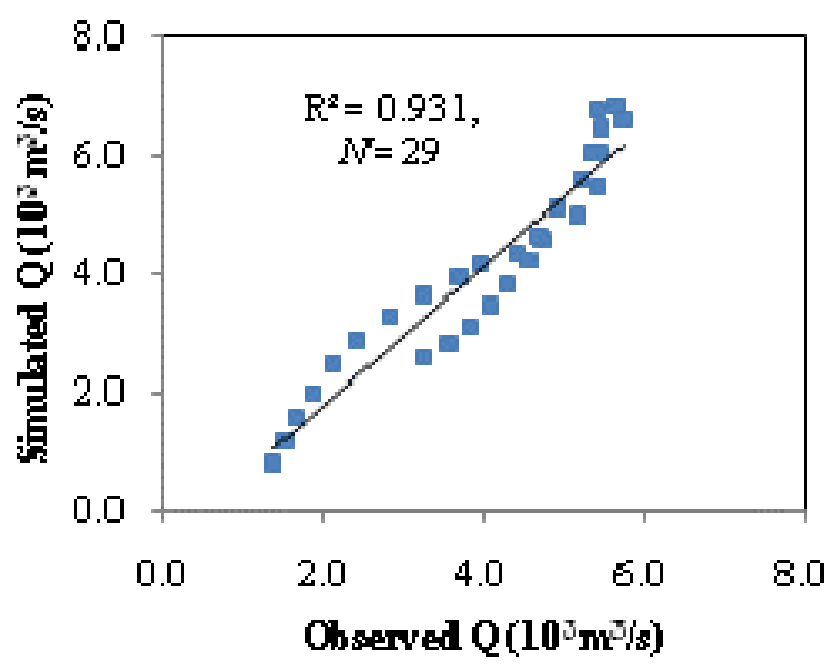

Fig. 10. Correlation of observed and simulated hourly water discharge at Tateyama (11 July 2002) ( $N$ =number of observations).

the observed and simulated results of hourly water discharge during peak flood hours on 11 July 2002 at Tateyama station. The simulation performance for hourly simulated water discharge is also found to be reasonable good with a corelation coefficient ( $R^{2}$ value) of 0.931 as shown in Fig. 10. Table 5 also shows a high Nash-Sutcliffe's Coefficient of 0.843 in the same comparison. High resolution spatial data is recomended for further improvement of simulation results at peak points.

The model has also well-simulated hourly suspended sediment (SS) discharge except during flood peak hours. Figure 11 shows observed and simulated hourly SS discharge with flow velocity at Tateyama station. There is a close match between the model results and the observed data when the $\mathrm{SS}$ discharge is lower than $2.0 \mathrm{~m}^{3} \mathrm{~s}^{-1}$. Figure 12 shows that the correlation value ( $R^{2}$ value) between observed and simulated SS discharge is 0.87 when SS discharge is less than 2.0

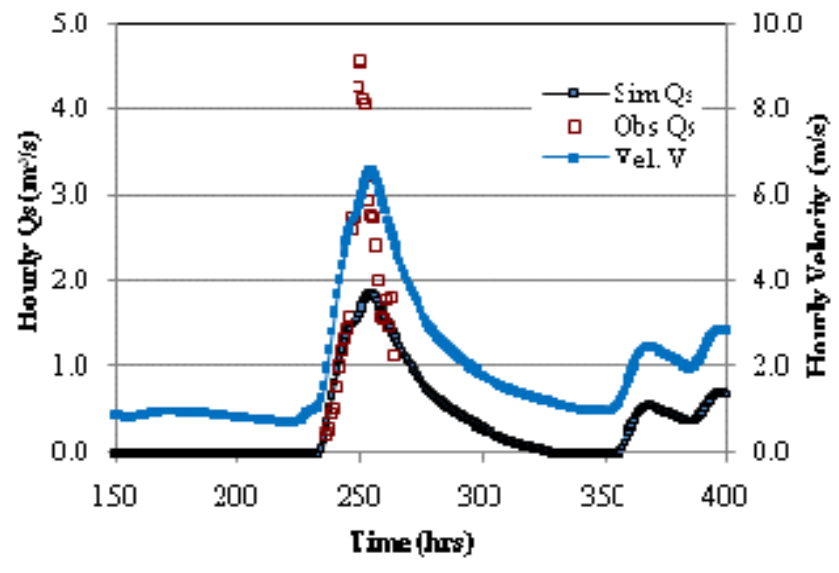

Fig. 11. Hourly suspended sediment discharge at Tateyama station (11 July 2002).

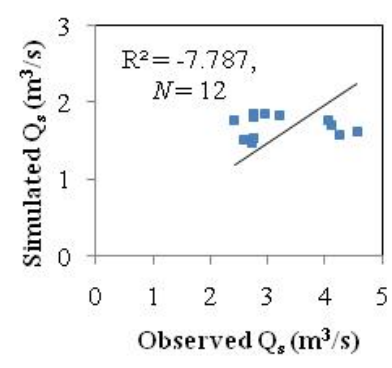

(a) Qs $>2 \mathrm{~m}^{3} / \mathrm{s}$

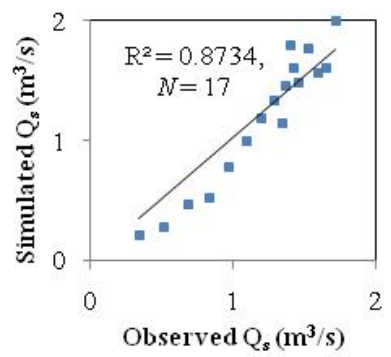

(b) Qs $<2 \mathrm{~m}^{3} / \mathrm{s}$
Fig. 12. Correlation of observed and simulated hourly suspended sediment discharge at Tateyama station $(N=$ number of observations).

$\mathrm{m}^{3} \mathrm{~s}^{-1}$ and it reveals a very poor relation when SS discharge is more than $2.0 \mathrm{~m}^{3} \mathrm{~s}^{-1}$ (Table 5). The Nash-Sutcliffe's coefficient of simulated SS discharge in comparison with observed SS discharge less than $2.0 \mathrm{~m}^{3} \mathrm{~s}^{-1}$ is also high $(0.88)$ (Table 5).

As described earlier, the Govers transport capacity equation has been applied to simulate suspended sediment transport in these model applications. It is worth mentioning that this transport capacity equation is based on unit stream power and median grain size $\left(d_{50}\right)$ values in limited conditions. The method considers an experimentally evaluated constant critical value of unit stream power to simulate suspended sediment transport. In this method, the recommended particle size ranges from 0.05 to $0.25 \mathrm{~mm}$ under the low flow conditions that are usually observed at rill locations. The transport capacity in Govers equation is less sensitive to flow velocity and slope of the basin. With these conditions, suspended sediment discharge in river systems is found to be reasonably consistent with channel flow as expected. 
On the other hand, grains smaller than $0.125 \mathrm{~mm}$ always behave as suspended sediment usually while grains coarser than $8.0 \mathrm{~mm}$ travel as bed load (Wilcock, 2004). There is no unique grain size in representing the boundary of these two loads since the processes are highly variable with flow strength. The flow at Tateyama exerted a higher degree of forces to river bed during peak flood hours on 11 July 2002 which increased suspended sediment ranges towards $8.0 \mathrm{~mm}$, far exceeding Govers threshold limit of $0.25 \mathrm{~mm}$. Therefore, the simulated suspended sediment values were found to be smaller than the observed value. Analyses considering sediment size class seperately with determining respective shear stress based transport capacity are recommended for simulating river sediment dynamics at high flow conditions.

\subsubsection{Sensitivity analysis}

A parametric study has also been carried out before the calibration. Soil particle size and density effects have been analysed since sediment transport involves the movement of different types of soil particles having large variability in both size and density (Nord et al., 2009). The effect of soil cohesion has also been investigated since it reflects the contribution of plant roots in soil detachment and the variation of top soil erodibility (Baets at el., 2008). In the calibrated condition, the soil density was considered as $2480 \mathrm{~kg} \mathrm{~m}^{-3}$ on average irrespective of the soil and land use classifications due to simplification of the problem. The ranges of particle sizes in terms of $d_{50}$ and soil cohesions were 75 to $125 \mu \mathrm{m}$ and 4.5 to $5.0 \mathrm{kPa}$, respectively in the calibrated condition. It is worth noting here that the soil particle size, density and cohesion have been considered based on the limited point sampling data mostly at Tateyama station.

Figure 13 shows simulated suspended sediment discharge $\left(Q_{\mathrm{s}}\right)$ in Abukuma River Basin at Tateyama station for two different soil densities with the observed one during July 2002. It revealed that the peak of suspended sediment discharge $\left(Q_{\mathrm{s}}\right)$ has increased by $11.40 \%$ for soil density $2650 \mathrm{~kg} \mathrm{~m}^{-3}$ in lieu of $2480 \mathrm{~kg} \mathrm{~m}^{-3}$. Suspended sediment discharge $\left(Q_{\mathrm{s}}\right)$ during peak hour of July 2002 is found to be increased by $15.56 \%$ and decreased by $14.79 \%$ due to the increase and decrease of $d_{50}$ value in each soil class by $10 \%$, respectively as shown in Fig. 14. The suspended sediment discharge $\left(Q_{\mathrm{s}}\right)$ is much sensitive with soil cohesion since a decrease of soil cohesion implies an increase of soil erodibility and a less effect of vegetation's encountering to soil erosion. Figure 15 shows that the peaks of suspended sediment discharge $\left(Q_{\mathrm{s}}\right)$ increase by $20.91 \%$ and decrease by $17.32 \%$ due to the decrease and increase of soil cohesion value by $5 \%$, respectively during same period.

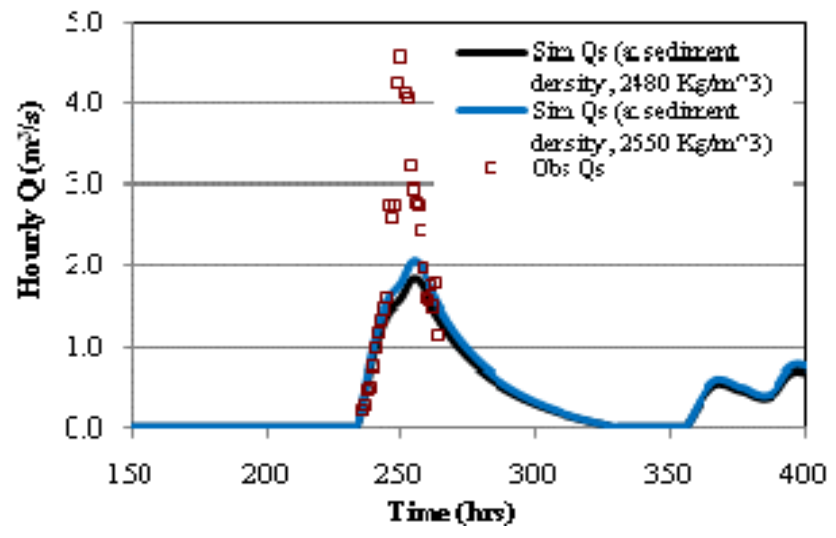

Fig. 13. $Q_{S}$ with different soil densities at Tateyama station.

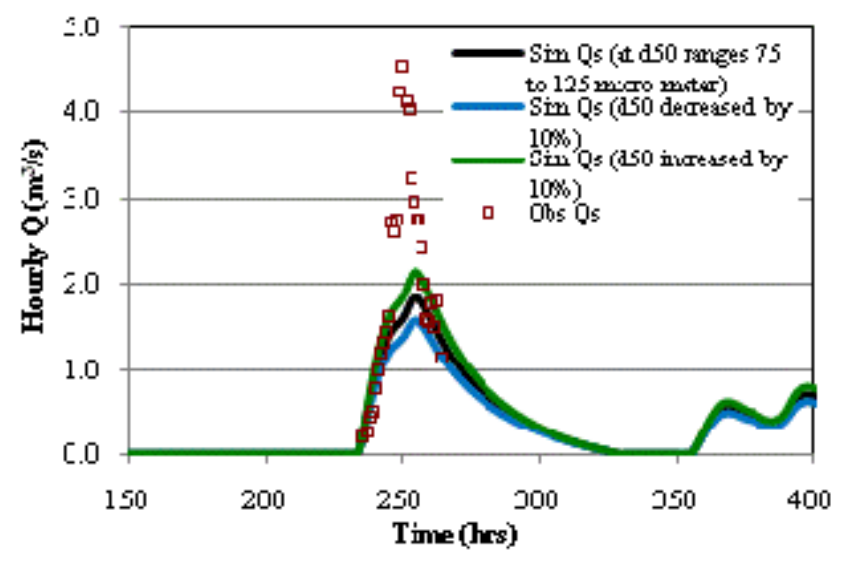

Fig. 14. $Q_{s}$ with different d50 values at Tateyama station.

\subsection{Study area 2 (Latrobe River Basin, Australia)}

Latrobe River Basin is located in south-eastern part of Victoria, Australia as shown in Fig. 16. The main stream of this watershed is Latrobe River, which flows eastwards throughout the whole basin and ultimately discharges into Lake Wellington. The central part of this basin is low elevated and covered with elongated flat farmland with unconsolidated soils, which are very much sensitive to bank erosion (DPI, 2009). The other parts excluding central region consist of steep mountains with fairly dense forest. The basin includes the three major towns of Moe, Morwell and Traralgon along its central part. The total basin area is around $4,675 \mathrm{~km}^{2}$ and it sustains a population of 97339 (BRS and BOM, 2008).

\subsubsection{Model setup}

In this study, the model has been set up to simulate flood events occurred in 2007 at Latrobe River Basin. The digital elevation model (DEM) of 500-m grid spacing has been used in simulation which was originally taken from SRTM data of 90-m resolution. The flow accumulation map and the major 


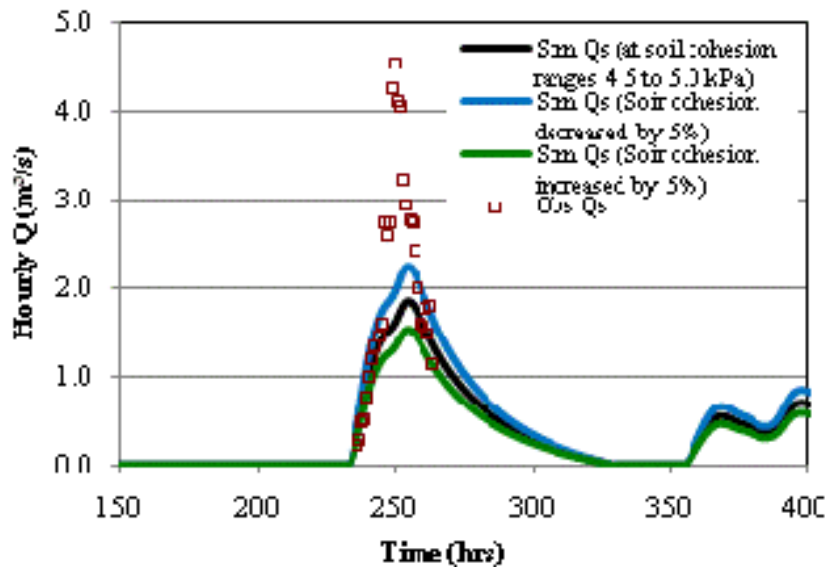

Fig. 15. $Q_{s}$ with different soil cohesion values at Tateyama station.

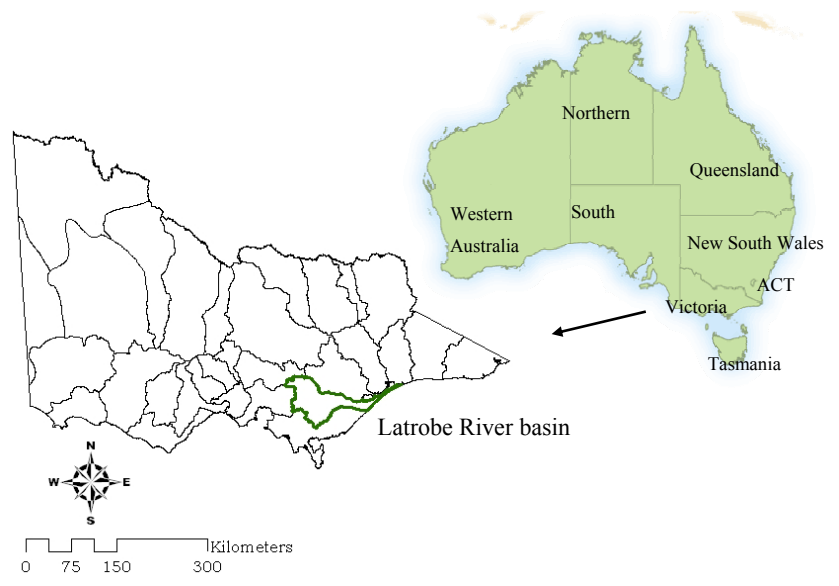

Fig. 16. Latrobe River Basin location in Victoria, Australia.

river network which have been generated from SRTM DEM are shown in Fig. 17a. Rosedale, Scarnes Bridge and Thoms Bridge are three gauging stations along the river network, which have been selected for calibration and verification of the model application. The maximum temporal resolution has also been set to 1-h during model simulation. Similar to Abukuma River Basin modeling, roughness coefficient $(n)$ values and an index of soil detachability $(k)$ have been considered main calibrating parameter in this case study. The major river network has been described in terms of hydraulic parameters associated with each of river branches to capture river flow dynamics properly. The different branches of Latrobe River have been named separately in this study as shown in Fig. 17b. Table 6 describes the hydraulic parameters of different river branches including calibrating terms that have used in model simulation.

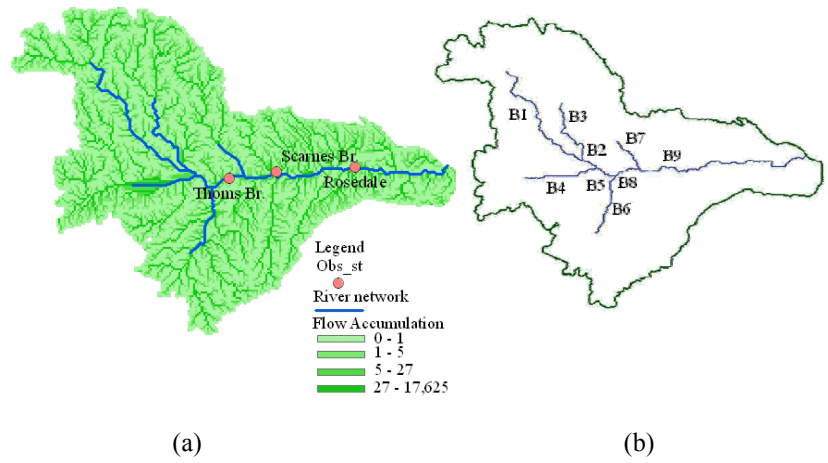

Fig. 17. Flow accumulation map and river network for Latrobe River Basin modeling.

\subsubsection{Simulations and discussion}

The total water budget allocation during 2007 flood periods (June to August) based on simulation results of different hydrological modules is $48.47 \%$ of infiltration, $39.42 \%$ of interception and evapotranspiration, $12.11 \%$ overland flow. It implies that a higher interception and evapotranspiration rate in Latrobe River Basin minimizes the amount of overland flow into the river systems. In 2007, the flood hydrographs in different stations revealed multiple peaks during June to August. Figure 18 shows observed and simulated results of water discharge at Rosedale points with basin average rainfall. The simulated results show much higher values in comparison with observed values during first flood peak hours. This is not surprising since the basin has a high soil moisture capacity that triggers a high infiltration rate (Potter et al., 2005) and the flooding conditions had started in this case just after a long dry spell. The actual runoff coefficient had significantly lower at that time than the constant or average runoff coefficient of the entire flood season. It has revealed that a runoff coefficient of 0.2 allocates water distributions properly for hydrological simulations at Latrobe River Basin when the basin antecedent soil moisture content is high.

The flood events in August 2007 occurred due to rainfall on wet basin condition. Flood event during this period have been simulated well by using the constant runoff coefficient. Figure 19 shows water and suspended sediment discharge at Rosedale and Scarnes Br., respectively with basin average rainfall. The model has well simulated daily water discharge in the study area and the correlation coefficients ( $R^{2}$ values) 0.935 and 0.877 at Rosedale and Scarnes Br., respectively are found in between simulated and observed daily water discharge as shown in Fig. 20. Table 7 presents the highest and lowest Nash-Sutcliffe's coefficient of 0.926 and 0.818 , respectively are also between simulated and observed daily water discharge at different river gauging stations during the flood event August 2007. 
Table 6. efinition of Latrobe River Branches for model simulation.

\begin{tabular}{lcccc}
\hline \multirow{2}{*}{ Model Rivers } & \multicolumn{4}{c}{ Model Descriptions } \\
\cline { 2 - 5 } & $\begin{array}{c}\text { River width } \\
(\mathrm{m})\end{array}$ & $\begin{array}{c}\text { River depth } \\
(\mathrm{m})\end{array}$ & $\begin{array}{c}\text { Manning's } \\
n\end{array}$ & $\begin{array}{c}k \text {-soil detachability } \\
\text { index }\left(\mathrm{g} \mathrm{j}^{-1}\right)\end{array}$ \\
\hline B1 (Latrobe River) & 13 & 2 & 0.030 & 1.6 \\
B2 (Latrobe River) & 15 & 2.5 & 0.030 & 1.5 \\
B3 (Tanjil River) & 20 & 3 & 0.020 & 1.3 \\
B4 (Moe River) & 12 & 7 & 0.040 & 1.6 \\
B5 (Lake Narracan) & 50 & 5 & 0.033 & 1.6 \\
B6 (Morwell River) & 13 & 5 & 0.045 & 1.7 \\
B7 (Tyers River) & 20 & 1.5 & 0.030 & 1.5 \\
B8 (Latrobe River) & 30 & 4 & 0.030 & 1.8 \\
B9 (Latrobe River) & 40 & 3 & 0.030 & 1.8 \\
\hline
\end{tabular}
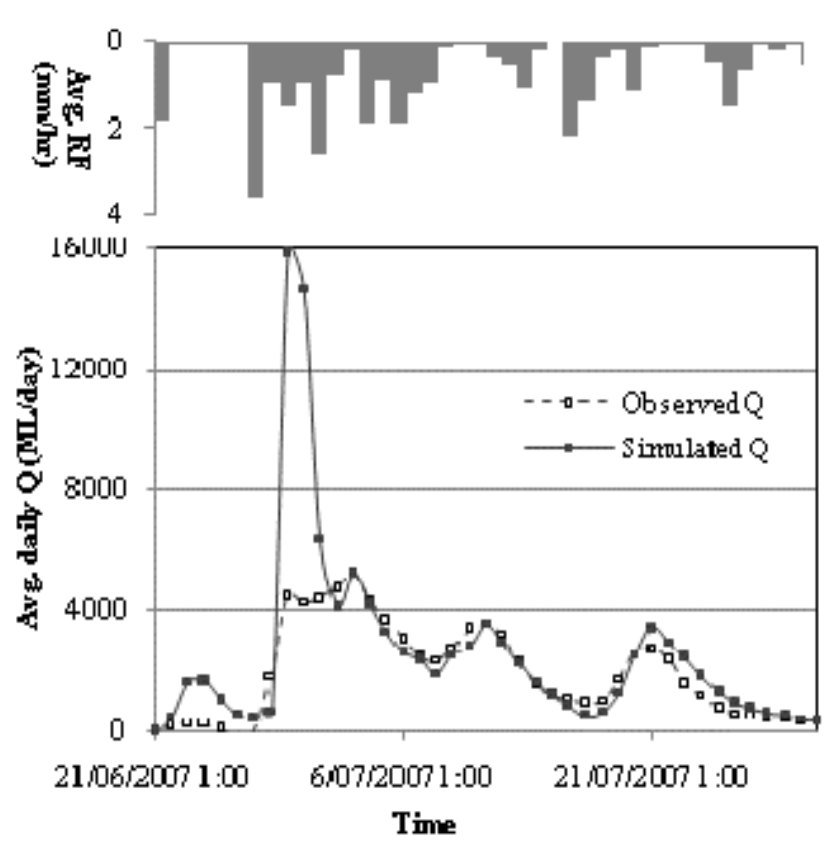

Fig. 18. Water discharge at Rosedale with basin avg. rainfall (ML = Mega liters).

Table 7. Performance evaluation of hydrological modeling at Latrobe River Basin.

\begin{tabular}{cclc}
\hline Items & No. of obs. & Stations & Nash-Sutcliffe COE \\
\hline \multirow{4}{*}{ Avg. daily, $Q$} & 29 & Rosedale & 0.926 \\
& 29 & Scarnes Br. & 0.830 \\
& 29 & Thoms Br. & 0.818 \\
\hline
\end{tabular}

The suspended sediment discharge at Rosedale and Scarnes Br. is found to follow a similar trend as on the water discharge along the river channels. A relatively smaller
Table 8. Performance evaluation of suspended sediment modeling at Latrobe River Basin.

\begin{tabular}{lccl}
\hline Items & Date of obs. & Stations & $\begin{array}{l}\% \text { of deviation at } \\
\text { single obs. }\end{array}$ \\
\hline \multirow{2}{*}{ Avg. daily, Qs } & $08 / 08 / 2007$ & Rosedale & +9.73 \\
& $08 / 08 / 2007$ & Scarnes Br. & +12.3 \\
\hline
\end{tabular}

portion from eroded soils from hillslope area reaches to the river systems due to less overland flow. On the other hand, many reservoirs along the river courses caused a decrease of flow velocity which promotes deposition of sediments of large particle sizes. Analyses of observed data revealed that the water discharge at Latrobe River delivered a limited force to channel systems during the flood events in August 2007 and in these circumstances, the suspended sediment concentration ranges were within the threshold limits of using the Govers transport capacity equation as discussed earlier. Therefore, simulated suspended sediments at different river gauging stations are found to be reasonable (less than $15 \%$ deviation) by comparing with a single observed data as described in Table 8.

\section{Conclusions}

A basin scale spatially distributed sediment dynamic model has been developed to simulate sediment dynamics with watershed rainfall-runoff characteristics and it was applied on two river basins in Japan and Australia. The model uses digital spatial datasets and divides the basin into an array of homogeneous grid cells. The model estimates sediment dynamics in hillslope areas using physical equations for soil detachment due to raindrop impact and the shearing force 


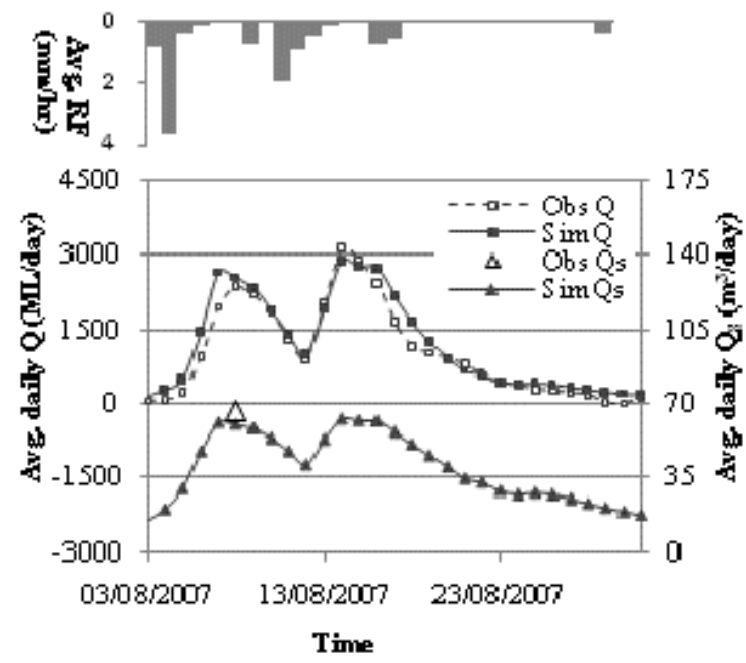

(a) At Rosedale
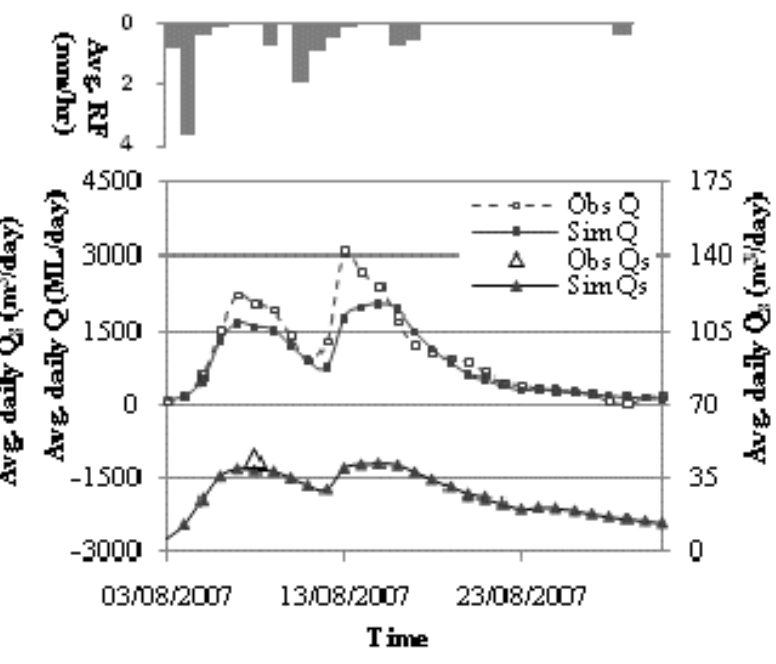

(b) At Scarnes Br.

Fig. 19. Water and suspended sediment discharge with basin avg. rainfall (ML= Mega liters).

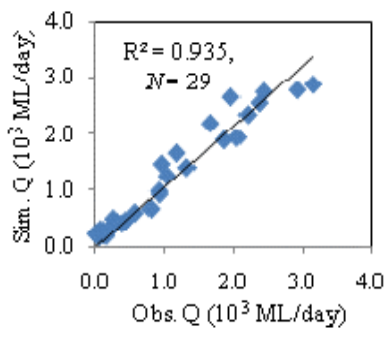

(a) At Rosedale

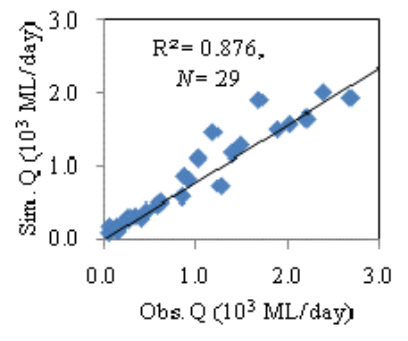

(b) At Scarnes Br.
Fig. 20. Correlation of observed and simulated water flow at Latrobe River $(N=$ number of observations, ML = Mega liters).

of flowing water whereas movements of flow and sediment particles are calculated using a backward finite difference algorithm based numerical solution of the kinematic wave approximation of the Saint-Venant equations. The Govers (1990) transport capacity equation and a set of constant runoff coefficients have been used in the model applications.

The model has well simulated runoff at Abukuma River Basin, Japan with highest and lowest Nash-Sutcliffe's coefficients of 0.986 and 0.843 , respectively at the different river gauging stations during the flood event of July 2002. The model has also satisfactorily calculated suspended sediment transport in the basin at low flow conditions. The correlations 0.515 and 0.780 using Nash-Sutcliffe efficiency and $R$-squar value, respectively have been found at Tateyama station with suspended sediment discharge less than $2.0 \mathrm{~m}^{3} \mathrm{~s}^{-1}$. This was expected due to the limitation associated with using Govers transport capacity equation at high flow conditions.
The Latrobe River Basin is highly dependent on the soil moisture antecedent conditions and thus, the simulation of July 2007 flood using a constant runoff coefficient gave erroneous results since the flood occurred just after a long dry spell. The model has performed well in simulating runoff at Latrobe River Basin, Australia with highest and lowest Nash-Sutcliffe's coefficient of 0.93 and 0.82 , respectively at different river gauging stations during the flood event $\mathrm{Au}-$ gust 2007. Based on the limited observed data, the model has also been found to be consistent in estimating suspended sediment transport in the two river systems.

In the two case study applications, constant runoff coefficients were used in the model instead of sub-surface simulations. The model performance can be further improved by incorporating sub-surface processes. The river module was used to estimate only suspended sediment load based on Govers (1990) transport capacity equation instead of simulating bed loads and the consideration of a wide ranges of particle size distributions in river systems. A limited verification was done in the Latrobe River Basin due to having less sediment data for the period of August 2007. Analyses of the model results with more observation data are recommended. Overall, the modeling concept reveals a way to develop a robust sediment dynamic model considering all relevant watershed parameters. 


\section{Appendix A}

\section{A list of symbols used in this paper}

\begin{tabular}{|c|c|c|}
\hline Symbol & Meaning & Unit \\
\hline$\beta_{\mathrm{s}}$ & Correction factor for cohesive soil erosion & - \\
\hline$\rho_{\mathrm{s}}$ & Soil density & $\mathrm{kg} \mathrm{m}^{-3}$ \\
\hline$\omega$ & Channel stream power & $\mathrm{cm} \mathrm{s}^{-1}$ \\
\hline$\omega_{\mathrm{cr}}$ & Critical stream power & $\mathrm{cm} \mathrm{s}^{-1}$ \\
\hline$\Delta x, \Delta t$ & Spatial, temporal intervals & meter, $\mathrm{s}$ \\
\hline$c, \eta$ & Coefficient related to particle size & - \\
\hline$A$ & Water flow cross-section & $\mathrm{m}^{2}$ \\
\hline$A_{\mathrm{s}}$ & Cross-section of sediment flow & $\mathrm{m}^{2}$ \\
\hline$C_{\mathrm{C}}$ & Canopy coverage factor & - \\
\hline$C_{\mathrm{s}}$ & Sediment concentration & $\mathrm{m}^{3} \mathrm{~m}^{-3}$ \\
\hline$d_{50}$ & Median grain size & $\mu \mathrm{m}$ \\
\hline$D_{\mathrm{m}}$ & Raindrop diameter & meter \\
\hline $\mathrm{DF}$ & Flow detachment or deposition & $\mathrm{m}^{3} \mathrm{~s}^{-1} \mathrm{~m}^{-1}$ \\
\hline DR & Soil detachment by rainfall & $\mathrm{m}^{3} \mathrm{~s}^{-1} \mathrm{~m}^{-1}$ \\
\hline$h$ & Depth of water & meter \\
\hline$H_{\text {net }}$ & Net rainfall depth & $\mathrm{mm}$ \\
\hline$H_{\text {Total }}$ & Total rainfall depth & $\mathrm{mm}$ \\
\hline$I$ & Rainfall intensity & $\mathrm{mm} \mathrm{h}^{-1}$ \\
\hline$i, j$ & Spatial, temporal points & - \\
\hline$J$ & Soil torvane shear strength & $\mathrm{kPa}$ \\
\hline$k$ & Soil detachability index & $\mathrm{gj}^{-1}$ \\
\hline $\mathrm{KE}(\mathrm{DT})$ & Kinetic energy due to direct rainfall & $\mathrm{jg}^{-1} \mathrm{~mm}^{-1}$ \\
\hline $\mathrm{KE}$ (LD) & Kinetic energy due to leaf drip & $\mathrm{jg}^{-1} \mathrm{~mm}^{-1}$ \\
\hline $\mathrm{KE}$ & Kinetic energy & $\mathrm{jg}^{-1}$ \\
\hline$n$ & Manning's roughness & - \\
\hline$N$ & No. of observations & - \\
\hline $\mathrm{np} 1, \mathrm{np} 2$ & Two consecutive river nodes & - \\
\hline$P$ & Wetted perimeter & meter \\
\hline $\mathrm{PH}$ & Canopy height & meter \\
\hline$q$ & Later water discharges & $\mathrm{m}^{2} \mathrm{~s}^{-1}$ \\
\hline$q_{\mathrm{s}}$ & Lateral sediment flow & $\mathrm{m}^{2} \mathrm{~s}^{-1}$ \\
\hline$Q$ & Water discharge & $\mathrm{m}^{3} \mathrm{~s}^{-1}$ \\
\hline$Q_{\mathrm{s}}$ & Sediment flow & $\mathrm{m}^{3} \mathrm{~s}^{-1}$ \\
\hline $\mathrm{RF}$ & Rainfall & $\mathrm{mm} \mathrm{h}^{-1}$ \\
\hline s & Land slope & $\%$ \\
\hline $\mathrm{TC}$ & Transport capacity concentration & $\mathrm{m}^{3} \mathrm{~m}^{-3}$ \\
\hline$V$ & Flow velocity & $\mathrm{m} \mathrm{s}^{-1}$ \\
\hline$v_{\mathrm{s}}$ & Particle settling velocity & $\mathrm{m} \mathrm{s}^{-1}$ \\
\hline W & Water flow width & meter \\
\hline$x, t$ & Distance, time & meter, s \\
\hline$Z$ & Soil texture index & - \\
\hline \multicolumn{3}{|c|}{$\begin{array}{l}P_{-} Q, P_{-} V, P_{-} C_{\mathrm{s}}, P_{-} q_{\mathrm{s}}: \text { Values of } Q, V, C_{\mathrm{s}}, q_{\mathrm{s}} \text { in previous } \\
\text { time intervals respectively }\end{array}$} \\
\hline
\end{tabular}

Acknowledgements. This project was funded by NEWJEC Inc., Japan and the small grant scheme of Monash University Gippsland Campus. The authors gratefully acknowledge the support. The three anonymous reviewers are acknowledged for their constructive criticism and valuable comments.

Edited by: M. Mikos

\section{References}

Aksoy, H. and Kavvas, M. L.: A review of hillslope and watershed scale erosion and sediment transport models, Catena, 64, 247$271,2005$.
Apip, Tachikawa, Y., Sayama, T., and Takara, K..: Lumping a physically-based distributed sediment runoff model with embedding river channel sediment transport mechanism, Annuals of Disas. Prev. Res. Inst., Kyoto University, No. 51 B, 2008.

Atkinson, E.: Methods for assessing sediment delivery in river systems, J. Hydrol. Sci., 40, 273-280, 1995.

Baets, S. D., Torri, D., Poesen, J., Salvador, M. P., and Meersmans, J.: Modeling increased soil cohesion due to roots with EUROSEM, Earth Surf. Proc. Land., 33, 1948-1963, 2008.

Beasley, D. B., Huggins, L. F., and Monke, E. J.: ANSWERS-A model for watershed planning, T. ASAE, 23, 938-944, 1980.

Bhattacharya, B., Price, R. K., and Solomatine, D. P.: Machine learning approach to modeling sediment transport, J. Hydraul. Eng., 133, 440-450, 2007.

Bhattarai, R. and Dutta, D.: Estimation of soil erosion and sediment yield using GIS at catchment scale, J. Water Res. Manage., 21, 1635-1647, 2007.

Borah, D. K. and Bera, M.: Watershed-scale hydrologic and nonpoint-source pollution models: review of mathematical bases, T. ASAE, 46, 1553-1566, 2003.

Brandt, C. J.: The size distribution of throughfall drops under vegetation canopies, Catena, 16, 507-524, 1989.

Brandt, C. J.: Simulation of size distribution and erosivity of raindrops and throughfall drops, Earth Surf. Proc. Land., 15, 687689, 1990.

Bureau of Rural Sciences (BRS) and Bureau of Meteorology (BOM).: Australia, July 2008 Latrobe River Basin Summary by CSIRO Online, http://adl.brs.gov.au/water2010/pdf/monthly_ reports/awap_226_report.pdf, last access: 1 April 2009, 2008.

Chmelova, R. and Sarapatka, B.: Soil erosion by water: contemporary research methods and their use, J. Geographica, 37, 23-30, 2002.

Chow, V. T.: Open channel flow, McGraw-Hill, New York, 294300, 1959.

Department of Primary Industries (DPI): Australia, A Guide to the Inland Angling Waters of Victoria, La Trobe River Basin, Online, available at: http://new.dpi.vic.gov.au/fisheries/ recreational-fishing/inland-angling-guide/?a=13398, last access: 14 April 2011, 2011.

Duna, S., Wua, J. Q., Elliot, W. J., Robichaudb, P. R., Flanaganc, D. C., Frankenbergerc, J. R., Brownb, R. E., and Xud, A. C.: Adapting the Water Erosion Prediction Project (WEPP) model for forest applications, J. Hydrol., 366, 46-54, 2009.

Dutta, D. and Nakayama, K.: Effects of spatial grid resolution on river flow and surface inundation simulation by physically based distributed modeling approach, J. Hydrol. Process, 23, 534-545, 2008.

Dutta, D., Herath, S., and Musiake, K.: Flood inundation simulation in a river basin using a physically based distributed hydrologic model, J. Hydrol. Process, 14, 497-519, 2000.

Ferro, V. and Porto, P.: Sediment Delivery Distributed (SEDD) model, J. Hydraul. Eng., 5, 411-422, 2000.

Fiener, P., Govers, G., and Oost, K. V.: Evaluation of a dynamic multi-class sediment transport model in a catchment under soilconservation agriculture, Earth Surf. Proc. Land., 33(11), 16391660, 2008.

Flanagan, D. C. and Nearing, M. A.: USDA-Water Environment Prediction Project: hillslope profile and watershed model documentation, NSERL. West Lafayette, USDA-ARS National Soil 
Erosion Research Laboratory, 1995.

Foster, G. R.: Modeling the erosion process., in Hydrological modeling in small watersheds, edited by: Haan, C. T., Jonson, H., and Beakensiek, D. L., American Society of Agricultural Engineers, St. Joseph, MI, 297-380, 1982.

Foster, G. R. and Meyer, L. D.: Transport of soil particles by shallow flow, T. ASAE, 15, 99-102, 1972.

Govers, G.: Empirical relationships for the transport capacity of overland flow, in Erosion, transport and deposition processes, edited by: International Association of Hydrological Sciences, 189, 45-63, 1990.

Gumiere, S. J., Le Bissonnais, Y., and Raclot, D.: Soil resistance to interrill erosion: Model parameterization and sensitivity, Catena, 77, 274-284, 2009.

Hograth, W. L., Parlange, J. Y., Rose, C. W., Sander, G. C., Steenhuis, T. S., and Barry, A.: Soil erosion due to rainfall impact with inflow: an analytical solution with spatial and temporal effects, J. Hydrol., 2995, 140-148, 2004.

Huggins, L. F. and Monke, E. J.: The mathematical simulation of the hydrology of small watersheds, Technical Report 1, Purdue University Water Resources Research Center, 1966.

Jain, M. K., Kothyari, U. C., and Ranga Raju, K. G.: GIS Based Distributed Model for Soil Erosion and Rate of Sediment Outflow from Catchments, J. Hydraul. Eng., 131, 755-769, 2005.

Jenson, S. K. and Domingue, J. O.: Extracting topographic structure from digital elevation model data for geographic information system analysis, Photogramm. Eng. Rem. S., 54(11), 1593-1600, 1988.

Laws, J. O. and Parsons, D. A.: The relation of raindrop size to intensity, Transactions, American Geophysical Union, 24, 542460, 1943

Merz, R., Blöschl, G., and Parajka, J.: Spatio-temporal variability of event runoff coefficients, J. Hydrol., 331(3-4), 591-604, 2006.

Morgan, R. P. C.: A simple approach to soil loss prediction: a revised Morgan-Morgan-Finney model, Catena, 44, 305-322, 2001

Morgan, R. P. C., Quinton, J. N., and Rickson, R. J.: EUROSEM user guide version 3.1, Silsoe College, Cranfield University, Silsoe, UK, 1993.
Morgan, R. P. C., Quinton, J. N., Smith, R. E., Govers, G., Poesen, W. A., Auerswald, K., Chisci, G., Torri, D., and Styczen, M. E.: The European Soil Erosion Model (EU-ROSEM): A dynamic approach for predicting sediment transport from fields and small catchments, Earth Surf. Proc. Land., 23, 527-544, 1998.

Mughal, H.: Regional scale soil erosion and sediment transport modeling, PhD Thesis, The University of Tokyo, Tokyo, 2001.

Nearing, M. A., Foster, G. R., Lane, L. J., and Finkner, S. C.: A process based soil erosion model for USDA water erosion prediction project technology, T. ASAE, 32, 1587-1593, 1989.

Noel, D. U.: A note on soil erosion and its environmental consequences in the United States, Water Air Soil Poll., 129, 181-197, 2001.

Nord, G., Esteves, M., Lapetite, J., and Hauet, A.: Effect of particle density and inflow concentration of suspended sediment on bedload transport in rill flow, Earth Surf. Proc. Land., 34, 253-263, 2009.

Park, S. W., Mitchell, J. K., and Scarborough, J. N.: Soil erosion simulation on small watersheds: A modified ANSWERS model, T. ASAE, 25, 1581-1588, 1982.

Post, D. A., Waterhouse, J., Grundy, M., and Cook, F.: The past, present and future of sediment and nutrient modeling in GBR catchments, A summary of CSIRO workshop 2006, Brisbane, Australia, 7-12, 2007.

Potter, N. J., Zhang, L., Milly, P. C. D., McMahon, T. A., and Jakeman, A. J.: Effects of rainfall seasonality and soil moisture capacity on mean annual water balance for Australian catchments, Water Resour. Res., 41(6), W06007, doi:10.1029/2004WR003697, 2005.

Smith, R. E., Goodrich, D., and Quinton, J. N.: Dynamic distributed simulation of watershed erosion: the KINEROS2 and EUROSEM models, J. Soil Water Conserv., 50, 517-520, 1995.

Svoray, T. and Ben-Said, S.: Soil loss, water ponding and sediment deposition variations as a consequence of rainfall intensity and land use: a multi-criteria analysis, Earth Surf. Proc. Land., 35, 202-216, 2010.

Torri, D., Sfalaga, M., and Del Sette, M.: Splash detachment: runoff depth and soil cohesion, Catena, 14, 149-155, 1987.

Wilcock, P. E.: Lecture Notes - Sediment Transport - The Sediment Problem, http://calm.geo.berkeley.edu/geomorph/wilcock/ WilcockSTLecture3.pdf, last access: 15 March 2009, 2004 